\title{
Antibacterial effect of Czech and Mānuka honey on selected mastitis pathogens
}

\author{
Marcela Klimešová, Irena Němečková, Eva Vondrušková, Ludmila Nejeschlebová \\ Dairy Research Institute, Prague, Czech Republic
}

Received May 28, 2018

Accepted December 7, 2018

\begin{abstract}
The work is focused on the antibacterial effect of four types of blossom honey, one honeydew and two Mānuka honey (MAN100+ and MAN400+) on selected pathogenic microorganisms isolated from cow's milk (Staphylococcus aureus 51 and S. aureus 428), sheep's milk (S. aureus 627), and from the Czech Collection of Microorganisms (Streptococcus uberis CCM 4617, Streptococcus agalactiae CCM 6187, Enterococcus faecalis CCM 4224 and Escherichia coli CCM 4787). The concentrations of honey samples were $20 \%$ and $30 \%$. The obtained results showed a $100 \%$ inhibitory effect of MAN $400+$ on all tested bacterial strains even at a concentration of $20 \%$ and also a comparable inhibitory effect of Mānuka honey with Czech honeydew. The results indicate that honey had an inhibitory effect against the tested bacterial species which may cause mastitis.
\end{abstract}

Blossom honey, honeydew, bacterial infection, mammary gland, inhibitory effect

Bacterial infection of the mammary gland (mastitis) is a frequent and costly disease not only in dairy cows, but in small ruminants such as sheep and goats, as well (Menzies and Ramanoon 2001; Leitner et al. 2004; Vyletělová et al. 2011; Manga and Vyletělová 2013; Gelasakis et al. 2015; Kvapilík et al. 2015). In general, mastitis is caused by pathogenic bacteria, especially Staphylococcus aureus, Streptococcus uberis, coagulase-negative staphylococci (CNS), Corynebacterium bovis, Streptococcus agalactiae, Escherichia coli and others (Hanuš et al. 1992; Hanuš et al. 2004; Vyletělová-Klimešová et al. 2014; Bogdanovičová et al. 2016). Due to the increasing number of antibiotic-resistant strains in both human and veterinary medicine, research is focused on the use of alternative antibiotic-free treatments. Among the resistant bacteria causing serious diseases are mainly methicillin-resistant $S$. aureus, vancomycin-resistant Enterococcus spp., multi-resistant Mycobacterium tuberculosis or carbapenem-resistant bacteria of the genus Enterobacteriaceae (Rattan et al. 1998; Lukášová and Šustáčková 2003; Vanderhaeghen et al. 2010; Gupta et al. 2011). One possibility of preventing mammalian infection is to use the antimicrobial effect of animal products containing plant substances, such as honey. Cooper et al. (1999) tested the sensitivity of $58 \mathrm{~S}$. aureus strains isolated from infected wounds to Mānuka and pasture honey and found no significant differences among the isolates in sensitivity to honey. Ali et al. (2005) also confirmed the inhibitory effect of honey, declared as fennel, on gram-positive and gram-negative mastitis pathogens ( $S$. aureus, Klebsiella pneumoniae, Pseudomonas aeruginosa, S. agalactiae, Proteus spp.). The use of honey in practice is mainly spread in New Zealand, where Mānuka honey is exclusively used for the treatment of mastitis infections (Allen and Molan 1997). However, the question remains whether any local honey could be as effective as Mānuka honey.

This work was therefore focused on verifying and comparing the antimicrobial effect of different types of honey originating from northern Moravia and New Zealand on selected bacterial pathogens that can cause mastitis. 


\section{Materials and Methods}

The origin of bacterial strains and honey samples

The tested strains were isolated from cow's milk suspected of mastitis (S. aureus 51 and S. aureus 428) and from sheep's milk (S. aureus 627). Other strains originated from the Czech Collection of Microorganisms in Brno (CCM; S. uberis CCM 4617, S. agalactiae CCM 6187, Enterococcus faecalis CCM 4224 and E. coli CCM 4787).

Seven kinds of honey (five from small sellers and two commercial) were tested: blossom honey $\mathrm{K}$ [the main content (38\%) of pollen from the Pyrus/Prunus-T family], BK (with $62 \%$ of pollen from the Cruciferae/ Brassicaceae family), S (with $82 \%$ of pollen from Cruciferae family) and MM (with $75 \%$ content of Cruciferae family pollen), honeydew M (with 74\% content of Myosotis sylvatica pollen) and commercial Mānuka honey (MAN100+ and MAN400+, Watson \& Son, New Zealand). Chemical compositions and more detailed pollen spectrum of the honey samples as measured by the Intertek Food Services, Bremen, Germany, are given in Tables 1,2 , and 3 .

Table 1. Chemical composition of tested honey (Intertek, Bremen).

\begin{tabular}{|c|c|c|c|c|c|c|}
\hline & Unit & $\mathrm{BK}$ & $\mathrm{K}$ & $S$ & $\mathrm{M}$ & MM \\
\hline Chloramphenicol & $\mu \mathrm{g} / \mathrm{kg}$ & n.d. & n.d. & n.d. & n.d. & n.d. \\
\hline HMF & $\mathrm{mg} / \mathrm{kg}$ & 1.8 & 4.3 & 5.4 & 2.1 & 6.3 \\
\hline Water content & $\%$ & 15.9 & 15.4 & 15.5 & 15.4 & 15.4 \\
\hline $\mathrm{pH}$ & & 4.1 & 4.1 & 4.0 & 4.7 & 4.4 \\
\hline Diastase & $\mathrm{DZ}$ & 16.2 & 10.3 & 14.8 & 20.7 & 21.9 \\
\hline Free acids & $\mathrm{mmol} / \mathrm{kg}$ & 12.7 & 15.4 & 15.2 & 28.3 & 18.0 \\
\hline Fructose F & $\mathrm{g} / 100 \mathrm{~g}$ & 37.8 & 39.0 & 38.8 & 33.3 & 38.2 \\
\hline Glucose G & $\mathrm{g} / 100 \mathrm{~g}$ & 39.0 & 37.2 & 38.3 & 28.5 & 36.1 \\
\hline Saccharose & $\mathrm{g} / 100 \mathrm{~g}$ & n.d. & 0.8 & n.d. & 0.7 & 0.5 \\
\hline Turanose & $\mathrm{g} / 100 \mathrm{~g}$ & 1.2 & 1.2 & 1.3 & 2.3 & 1.6 \\
\hline Maltose & $\mathrm{g} / 100 \mathrm{~g}$ & 1.6 & 1.8 & n.d. & 2.1 & 2.2 \\
\hline $\mathrm{F} / \mathrm{G}$ ratio & & 0.97 & 1.05 & 1.01 & 1.17 & 1.6 \\
\hline Invert sugar $(\mathrm{F}+\mathrm{G})$ & $\mathrm{g} / 100 \mathrm{~g}$ & 76.8 & 76.2 & 77.1 & 61.8 & 74.3 \\
\hline Conductivity & $\mathrm{mS} / \mathrm{cm}$ & 0.21 & 0.18 & 0.15 & 1.07 & 0.32 \\
\hline
\end{tabular}

$\mathrm{K}, \mathrm{BK}, \mathrm{S}, \mathrm{MM}=$ blossom honey; $\mathrm{M}=$ honeydew; $\mathrm{HMF}=$ hydroxymethylfurfural; n.d. = not detected

The testing procedure for the inhibitory effect of honey

Blood agar (without the addition of blood) was prepared to contain honey at the concentrations of $20 \%$ and $30 \%$. Honey was homogenized in sterile distilled water and added to the agar base after sterilization and cooling to $45 \pm 1^{\circ} \mathrm{C}$. Afterwards, the dilution plate method was performed (ČSN EN ISO 7218,2008 ). The tested bacteria were suspended in sterile distilled water and the relevant dilution at a volume of $0.1 \mathrm{ml}$ was inoculated onto the surface of agar with honey and incubated at $37 \pm 1^{\circ} \mathrm{C}$ for $24-48 \mathrm{~h}$. The total count of colonies was determined in $\mathrm{cfu} \cdot \mathrm{ml}^{-1}$ and the results were expressed as a percentage of inhibited bacteria. For this purpose, blood agar without the addition of honey or sugar was used as bacterial growth control. Another control modelling the osmotic pressure of honey was blood agar containing $20 \%$ and $30 \%$ of honey sugars: fructose $(38.2 \%)$, sucrose $(1.3 \%)$, maltose (7.3\%) and glucose (31.3\%) according to Belitz and Grosch (1992).

\section{Statistical analysis}

Paired $t$-test was used to compare variables between MAN400+ as a reference honey and others species of honey on the mastitis set of pathogens (MS Excel - Microsoft, Redmond, Washington, USA). $P$ values $<0.05$ were considered significant.

\section{Results}

The results regarding the inhibitory effect of honey samples are summarized in Table 4 . For the $20 \%$ concentration of honey, the most significant inhibition $(100 \%)$ of all the tested strains was found for honey MAN400+. Besides that, honey samples M, MM and MAN100+ significantly (60-100\%) inhibited S. aureus and Streptococcus spp. strains while honey K was effective (89-94\%) only against $S$. uberis and S. agalactiae. 
Table 2. Pollen spectrum in the tested honey (Intertek, Bremen).

\begin{tabular}{|c|c|}
\hline Blossom honey K & $\%$ \\
\hline Pyrus/Prunus-T, Rosaceae, Fruit-T & 38 \\
\hline Crucifereae, Cruciferae, Crucifers (Brassicaceae) & 20 \\
\hline Salix, Saliceae, Willow & 8 \\
\hline Phacelia-T, Hydrophyllaceae, Bluebell & 4 \\
\hline Others & $<3$ \\
\hline Blossom honey BK & $\%$ \\
\hline Crucifereae, Cruciferae, Crucifers & 62 \\
\hline Pyrus/Prunus-T, Rosaceae, Fruit-T & 20 \\
\hline Salix, Saliceae, Willow & 5 \\
\hline Others & $<3$ \\
\hline Blossom honey S & $\%$ \\
\hline Crucifereae, Cruciferae, Crucifers & 82 \\
\hline Pyrus/Prunus-T, Rosaceae, Fruit-T & 10 \\
\hline Others & $<3$ \\
\hline Blossom honey MM & $\%$ \\
\hline Crucifereae, Cruciferae, Crucifers & 75 \\
\hline Pyrus/Prunus-T, Rosaceae, Fruit-T & 11 \\
\hline Acer, Aceraceae, Maple & 7 \\
\hline Others & $<3$ \\
\hline Honeydew M & $\%$ \\
\hline Myosotis-T, Boraginaceae, Forget-me-not & 74 \\
\hline Salix, Saliceae, Willow & 8 \\
\hline Trifolium-T, Leguminosae, Clover- $T$ & 5 \\
\hline Umbellieferae, Umbellifers & 4 \\
\hline Others & $<3$ \\
\hline
\end{tabular}

For $30 \%$ concentration of honey, only samples MAN100+ and M had comparable effects with Mānuka honey MAN400+ on all the tested strains $(97-100 \%)$. Except for $S$. aureus 428 and 627, honey samples $\mathrm{MM}$ and $\mathrm{BK}$ were significantly effective $\quad(68-100 \%, \quad 71-98 \%$, respectively) as well. Nevertheless, it is important to consider the relatively high inhibitory effect of control $30 \%$ sugar solution on $S$. uberis and $S$. agalactiae $(22 \%$ and $28 \%$, respectively).

Among the tested samples, Mānuka honey MAN400+ showed the highest inhibitory effect at both concentrations of $20 \%$ and $30 \%$. The effectivity of other samples was in the sequence: honeydew M and honey MAN100+ as comparable with a very good effect, followed by honey MM, then honey $\mathrm{BK}$ and $\mathrm{K}$, with honey $\mathrm{S}$ being the weakest.

No significant difference was found between MAN400+ and $\mathrm{M}$ at both concentrations, between MAN400+ and $\mathrm{MM}$ at a $20 \%$ concentration, and MAN400+ and BK and MAN100+ at a $30 \%$ concentration (Table 5 ).

As a whole, the microorganis-ms

Table 3. Mānuka honey - chemical characteristics declared by the manufacturer and pollen content according to Intertek, Bremen.

\begin{tabular}{lll}
\hline & $\begin{array}{l}\text { MAN400+ } \\
\text { per } 100 \mathrm{~g}\end{array}$ & $\begin{array}{l}\text { MAN100+ } \\
\text { per } 100 \mathrm{~g}\end{array}$ \\
\hline Energy & $1375 \mathrm{~kJ}$ & $1375 \mathrm{~kJ}$ \\
Proteins & $0.2 \mathrm{~g}$ & $0.2 \mathrm{~g}$ \\
Fat in total & $0.9 \mathrm{~g}$ & $0.9 \mathrm{~g}$ \\
Saturated fatty acids & $0.6 \mathrm{~g}$ & $0.6 \mathrm{~g}$ \\
Carbohydrates in total & $78.5 \mathrm{~g}$ & $78.5 \mathrm{~g}$ \\
Sugar & $76.2 \mathrm{~g}$ & $76.2 \mathrm{~g}$ \\
Salt & $20 \mathrm{mg}$ & $20 \mathrm{mg}$ \\
Methylglyoxal & $400 \mathrm{mg} / \mathrm{kg}$ & $100 \mathrm{mg} / \mathrm{kg}$ \\
Pollen & Leptospermum-T, & Leptospermum-T, \\
& Myrtaceae, Tea Tree $(91 \%)$ & Myrtaceae, Tea Tree $(91 \%)$ \\
\hline
\end{tabular}
most sensitive to honey were bacteria of the genus Streptococcus at both concentrations of honey. Furthermore, the highest inhibitory effect at the concentration of $20 \%$ was found for Staphylococcus strains, followed by $E$. faecalis and E. coli. At the higher concentration of $30 \%$, the order of sensitivity was as follows: $E$. coli, E. faecalis, and Staphylococcus spp.

\section{Discussion}

In general, both Mānuka honey samples showed the highest inhibitory effect at both concentrations of $20 \%$ and $30 \%$ which was most likely caused by the presence 


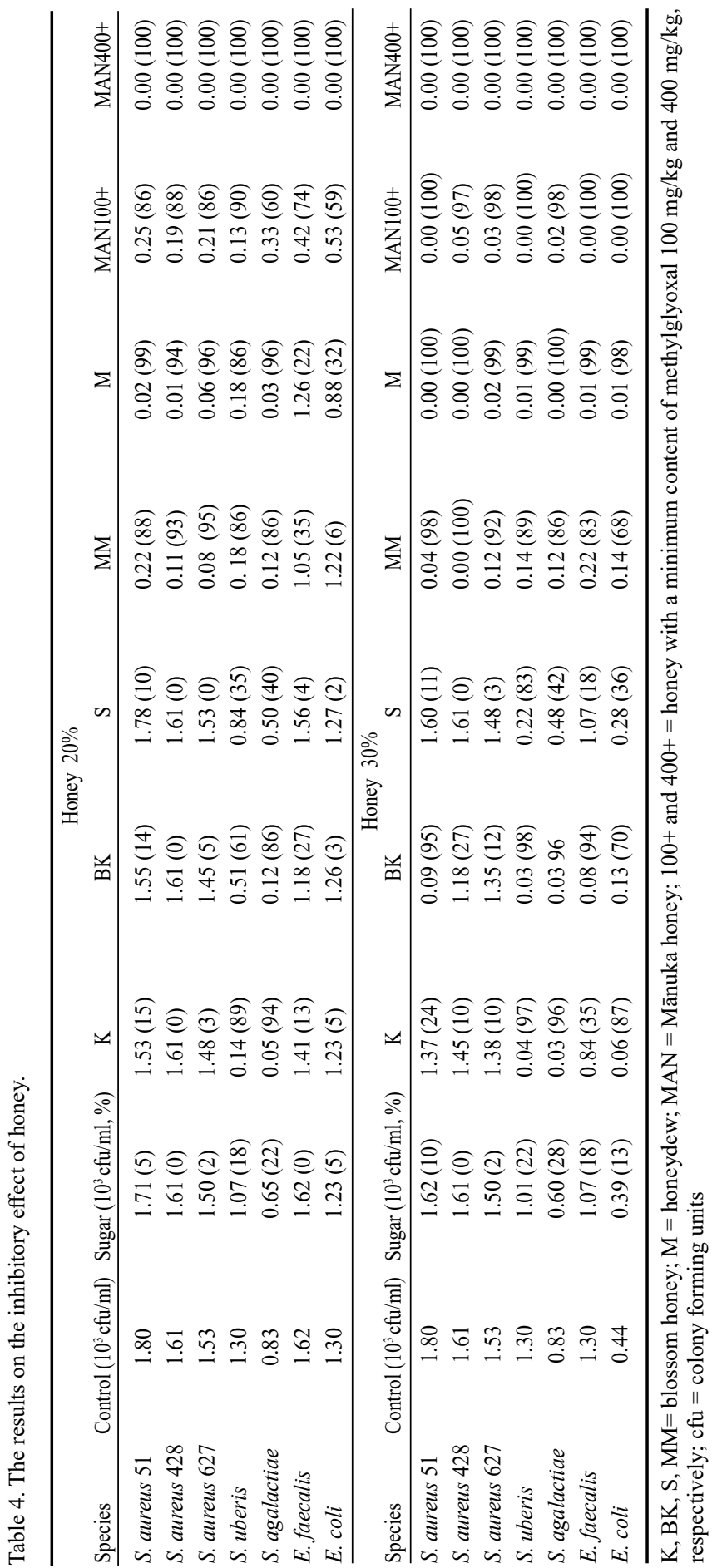

of methylglyoxal (MGO). This substance was identified as the predominant antibacterial component of Mānuka honey (Chaki et al. 2010; Hayashi et al. 2014). Most publications on the antibacterial effect of honey are dedicated to gram-positive bacteria, especially $S$. aureus, and their results are comparable with our findings. Almasaudi et al. (2017) compared the effect of honey samples against $S$. aureus. Five types of honey (Mānuka honey UMF +20/MGO 829+, Mānuka honey UMF +16/MGO 572+, Active +10/MGO 263+ Mānuka honey, Sidr honey and Nigella sativa honey) were evaluated for their bactericidal/ bacteriostatic activities against both methicillinresistant and sensitive $S$. aureus. The inhibitory effect of honey was evident at concentrations of $20 \%$ and even $10 \%$. Mānuka honey showed the best results. Cooper et al. (1999) tested the susceptibility of $58 \mathrm{~S}$. aureus strains isolated from infected wounds to Mānuka and pasture honey and reported that these honey types could prevent $S$. aureus from growing even when diluted with body fluids seven to fourteen times. The authors declared, that the antibacterial effect of pasture honey consists in the release of hydrogen 


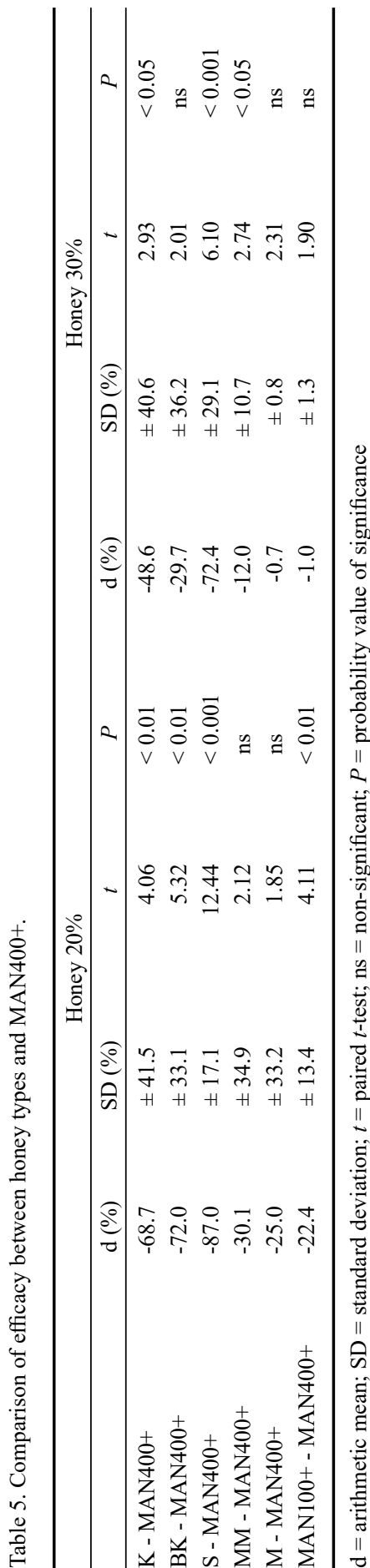

peroxide, which can be reduced in vivo by the catalase activity in tissues or blood. The effect of Mānuka honey originates partly from hydrogen peroxide and partly from the phytochemical component $\mathrm{MGO}$, so this type of honey may be more effective in vivo. In their later work, Cooper et al. (2002) tested Mānuka and pasture honey against eighteen strains of methicillin-resistant $S$. aureus, seven strains of vancomycin-sensitive enterococci isolated from infected wounds and twenty strains of vancomycin-resistant enterococci isolated from hospital environmental surfaces using an agar incorporation technique to determine minimum inhibitory concentration (MIC). For all of the strains tested, the MIC values for Mānuka and pasture honey were below $10 \%(\mathrm{v} / \mathrm{v})$. However, the concentration of artificial honey required to achieve equivalent inhibition in vitro was at least three times higher. Mousa et al. (2012) tested different concentrations of honey (undiluted honey, 10\%, 30\%, 50\% and 70\% v/v) against $S$. aureus and Streptococcus pyogenes by the disc diffusion method in vitro and concluded that these honey samples were comparable with standard antibiotics as ampicillin, penicillin $\mathrm{G}$, amoxicillin, gentamicin, tobramycin, erythromycin and chloramphenicol.

In this study, comparable results with MAN 100+ were achieved by honeydew M. Its high activity can be explained by a higher content of mineral substances, which is typical for honeydews. Likewise, high inhibitory effect was found for MM honey containing the highest content of mineral substances among the tested blossom honey samples. This characteristic is manifested by higher conductivity $(0.32 \mathrm{mS} / \mathrm{cm})$. Honey B and BK showed similar effects at a $20 \%$ concentration; however, at a $30 \%$ concentration, honey BK was more effective. This difference can be explained by the pollen composition and contents of hydroxymethylfurfural and diastase. The weakest inhibitory effect was shown in honey $\mathrm{S}$, although its composition was very similar to honey BK. It differed only in a higher content of pollen grains of the family Crucifereae and a lower content of family Rosaceae.

The antibacterial influence of honey samples was confirmed on both gram-positive and gram-negative bacteria in our study. Wilkinson and Cavanagh (2005) tested the antibacterial effect of thirteen honey samples (including three commercial ones) on gramnegative bacteria $E$. coli and $P$. aeruginosa, achieving results comparable with our findings on $E$. coli. The antibacterial activity of honey was tested using standard diffusion methods with honey samples at four 
concentrations $(10 \%, 5 \%, 2.5 \% \mathrm{w} / \mathrm{v})$. All of the tested honey types had an inhibitory effect on the growth of $E$. coli and $P$. aeruginosa, one of the honey samples still acted against $E$. coli and three showed anti-P. aeruginosa activity at $2.5 \%$. This study showed that several honey types, besides the commercial antibacterial honey, can inhibit E. coli and P. aeruginosa and may have a therapeutic potential in the case of Gram-negative bacteria.

The use of honey as a wound dressing is well known in both traditional and modern medicine. Many studies have reported the effectivity of honey in the removal of bacterial infections in ulcers and abscesses and indicate that it may be suitable for the intramammary treatment of mastitis. Allen and Molan (1997) tried out the sensitivity of bacteria (Actinomyces pyogenes, $K$. pneumoniae, Nocardia asteroides, S. aureus, $S$. agalactiae, Streptococcus dysgalactiae, $S$. uberis) that usually cause mastitis in dairy cows to antibacterial honey activity. The growth of all seven species tested was completely inhibited by a typical honey (with antibacterial activity attributed to its content of hydrogen peroxide) at a concentration of $10 \%(\mathrm{v} / \mathrm{v})$ in agar plates. Moreover, two species were inhibited even by $5 \%$ honey.

The obtained results indicate that honey could be a suitable raw material for the production of natural sustainable products applicable as alternative therapy in the case of mastitis or during the cow's drying period, as well as for protection against the spreading of pathogenic and resistant microorganisms in dairy production. This study presents preliminary results and a more detailed study should be conducted in the near future.

\section{Acknowledgements}

This work was supported by Ministry of Agriculture of Czech Republic by the project NAZV KUS QJ1510047 and QJ1510339 and decision No. RO1418

\section{References}

Ali M, Wahba N, Abdel-Rahman M, Abdel-Hafeez MM 2005: Antibacterial activity of honey for treatment of subclinical bovine mastitis: 1- In vitro study of bacterial inhibitions and chemical bioassay of some different honeys, Conference: $8^{\text {th }}$ Sci. Cong., Egyptian Society For Cattle Diseases, 11-13 Dec 2005, Assiut, Egypt

Allen KL, Molan PC 1997: The sensitivity of mastitis-causing bacteria to the antibacterial activity of honey. New Zealand J Agric Res 40: 537-540

Almasaudi SB, Al-Nahari AAM, El-Ghany ESMA, Barbour E, Muhayawi SMA, Al-Jaouni S, Azhar E, Qari M, Qari YA, Harakeh S 2017: Antimicrobial effect of different types of honey on Staphylococcus aureus. Saudi J Biol Sci 24: 1255-1261

Belitz HD, Grosch W 1992: Lehrbuch der Lebensmittel - chemie. 4. Auflage. Springer-Verlag, Berlin, 966 p.

Bogdanovičová K, Vyletělová-Klimešová M, Babák V, Kalhotka L, Koláčková I, Karpíšková R 2016: Microbiological quality of raw milk in the Czech Republic. Czech J Food Sci 34: 189-196

Chaki S, Mukherjee S, Das S, Mookerjee M, Dastidar SG 2010: Evaluation of bactericidal action of methylglyoxal and its further potentiation in the presence of honey. Int J Biom Pharm Sci 4: 66-69

Cooper RA, Molan PC, Harding KG 1999: Antibacterial activity of honey against strains of Staphylococcus aureus from infected wounds. J Royal Soc Med 92: 283-285

Cooper RA, Molan PC, Harding KG 2002: The sensitivity to honey of gram-positive cocci of clinical significance isolated from wounds. J Appl Microbiol 93: 857-863

Czech technical standard ČSN EN ISO 7218 2008: Microbiology of food and animal feeding stuffs - General requirements and guidance for microbiological examinations. Czech Standards Institute, Praha, $68 \mathrm{p}$.

Gelasakis AI, Mavrogianni VS, Petridis IG, Vasileiou NGC, Fthenakis GC 2015: Mastitis in sheep - The last 10 years and the future of research. Vet Microbiol 181: 136-146

Gupta N, Limbago BM, Patel JB, Kallen AJ 2011: Carbapenem-resistant Enterobacteriaceae: epidemiology and prevention. Clin Inf Dis 53: 60-67

Hanuš O, Frelich J, Vyletělová M, Roubal P, Vorlíček Z, Jedelská R 2004: Technologically difficult, pathogenic and food risky bacterial contamination of raw milk and other materials from dairy cow herds. Czech J Animal Sci 49: 489-499

Hanuš O, Žváčková I, Genčurová V, Gabriel B 1992: A relationship between milk lactose content and indicators of the mammary gland health in the first third of lactation. Vet Med 37: 595-604

Hayashi K, Fukushima A, Hayashi-Nishino M, Nishino K 2014: Effect of methylglyoxal on multidrug-resistant Pseudomonas aeruginosa. Front Microbiol 5: 1-6 
Kvapilík J, Hanuš O, Bartoň L, Vyletělová Klimešová M, Roubal P 2015: Mastitis of dairy cows and financial losses: an economic meta-analysis and model calculation. Bulg J Agri Sci 21: 1092-1105

Leitner G, Chaffer M, Shamay A, Shapiro F, Merin U, Ezra E, Saran A, Silanikove N 2004: Changes in milk composition as affected by subclinical mastitis in sheep. J Dairy Sci 87: 46-52

Lukášová J, Šustáčková A 2003: Enterococci and antibiotic resistance. Acta Vet Brno 72: 315-323

Manga I, Vyletělová M 2013: A new real-time PCR assay for rapid identification of the S. aureus/MRSA strains. Acta Univ Agric Silvic Mendelianae Brun LXI: 1785-1792

Menzies PI, Ramanoon SZ 2001: Mastitis of sheep and goats. Vet Clinics North Amer: Food Animal Practice 17: 333-358

Mousa A, Noureddine D, Mohamed HS, Abdelmelek M, Saad A 2012: Antibacterial activity of various honey types of Algeria against Staphylococcus aureus and Streptococcus pyogenes. Asian Pac J Trop Med 5: 773-776

Rattan A, Kalia A, Ahmad N 1998: Multidrug-resistant Mycobacterium tuberculosis: molecular perspectives. Emerg Inf Dis 4: 195-209

Vanderhaeghen W, Cerpentier T, Adriaensen C, Hermans JK, Butaye P 2010: Methicillin-resistant Staphylococcus aureus (MRSA) ST398 associated with clinical and subclinical mastitis in Belgian cows. Vet Microbiol 144: 166-171

Vyletělová-Klimešová M, Hanuš O, Dufek A, Němečková I, Horáček J, Ponížil A, Nejeschlebová L 2014: Staphylococcus aureus and other pathogens in relation to breed of cattle and somatic cell count. Bulg J Agric Sci 20: 1495-1500

Vyletělová M, Vlková H, Manga I 2011: Occurrence and characteristics of methicillin resistant Staphylococcus aureus and methicillin resistant coagulase-negative Staphylococci in raw milk manufacturing. Czech J Food Sci 29: 11-16

Wilkinson JM, Cavanagh HM 2005: Antibacterial activity of 13 honeys against Escherichia coli and Pseudomonas aeruginosa. J Med Food 8: 100-103 